\title{
SARS-CoV-2 Pozitif Hastaların Klinik Olarak Sınıflandırılması; Laboratuvar ve Radyolojik Bulgularının Deg̃erlendirilmesi
}

\section{Clinical Classification of SARS-CoV-2 Positive Patients; Evaluation of Laboratory and Radiological Findings}

Șinasi KARVAR'(IID), Harun GÜLBUDAK'(IID), Yusuf GÖRGÜLÜ'(IiD), Seda TEZCAN ÜLGER'(IID),

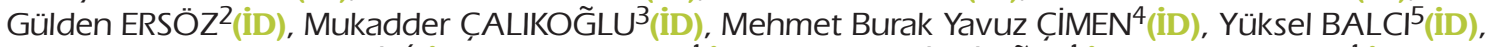
Asena Ayça ÖZDEMIR (IID), Gamze YAPICI'(IID), Nuran DELIALIOG̃LU'(IID), Gönül ASLAN'(IID)

\footnotetext{
${ }^{1}$ Mersin Üniversitesi Tıp Fakültesi, Tıbbi Mikrobiyoloji Anabilim Dalı, Mersin, Türkiye

2 Mersin Üniversitesi Tıp Fakültesi, İnfeksiyon Hastalıkları ve Klinik Mikrobiyoloji Anabilim Dalı, Mersin, Türkiye

${ }^{3}$ Mersin Üniversitesi Tıp Fakültesi, Göğüs Hastalıkları Anabilim Dalı, Mersin, Türkiye

${ }^{4}$ Mersin Üniversitesi Tıp Fakültesi, Tıbbi Biyokimya Anabilim Dalı, Mersin, Türkiye

${ }^{5}$ Mersin Üniversitesi Tıp Fakültesi, Radyoloji Anabilim Dalı, Mersin, Türkiye

${ }^{6}$ Mersin Üniversitesi Tıp Fakültesi, Tıp Eg̃itimi Anabilim Dalı, Mersin, Türkiye
}

\section{ÖZ}

Giriş: SARS-CoV-2'nin neden olduğu Coronavirus hastalığı 2019 (COVID-19) pandemisinin aniden ortaya çıkması ve hızla yayılması, küresel sağlığı tehlikeye atmıștır. Bu sebeple virüsün yayılmasını kontrol altına alacak stratejilerin geliștirilmesine acilen ihtiyaç duyulmaktadır. Bu çalışmada SARS-CoV-2 ters transkripsiyonlu kantitatif polimeraz zincir reaksiyonu (RT-qPCR) sonucu pozitif olguların klinik, laboratuvar ve toraks bilgisayarlı tomografi (BT) bulgularının değerlendirilmesi amaçlanmıştır.

Materyal ve Metod: 15 Nisan 2020 ile 31 Ağustos 2020 tarihleri arasında SARS-CoV-2 RT-qPCR sonucu pozitif olan, laboratuvar ve toraks BT tetkiklerine ulaşılan 18 yaş ve üstü toplam 278 hasta çalışmaya dahil edildi. Hastaların kliniğine göre; asemptomatik, hafif ve ağır olarak sınıflandırılması yapıldı. Hastaların demografik bilgileri, laboratuvar tetkikleri ve toraks BT sonuçları hastane sistemi ve ilgili branş hekimlerinden alınan verilerle oluşturuldu. Veriler daha sonra istatistiksel olarak analiz edildi.

Bulgular: Çalışmadaki hastaların 150 (\%54)'si erkek 128 (\%46)'i kadındı. Bu hastaların 42 (\%15)'si asemptomatik, 200 (\%72)'ü hafif ve 36 (\%13)'sı ağır klinik olarak sınıflandırıldı. Hastaların yaş ortalaması $45.5 \pm 17.5$ yıl olarak bulundu ve 72 (\%25.9) hastanın en az bir komorbiditesi olduğu tespit edildi. Hastaların \%42.4 (118/278)'ünün toraks BT tetkiklerinde COVID-19 pnömonisi ile uyumlu bulgu gözlendi. Ağır klinik hastaların toraks BT'sinde bulgu görülme oranı (\%91.7), hafif (\%38.5) ve asemptomatik hastalara (\%19) göre yüksek bulundu $(p<0.05)$. Laboratuvar bulgularını incelendiğinde hastaların \%59.4'ünde CRP yüksekliği, \%42.1'inde lenfopeni, \%41. 1 'inde LDH yüksekliği, \%40.6'sında kreatinin yüksekliği, \%36'sında AST yüksekliği, \%20.1'inde lökopeni, \%8'inde ALT yüksekliği, \%7.2'sinde lökosit yüksekliği, \%5.4'ünde troponin I yüksekliği, \%3.3'ünde CK-MB yüksekliği tespit edildi. Ağır klinik hastalarda lenfopeni (\%83.3), nötrofil yüksekliği (\%41.7), CRP yüksekliği (\%97.2), LDH yüksekliği (\%91.3), troponin I yüksekliği (\%21.4) ve AST yüksekliği (\%63.9) bulguları asemptomatik ve hafif klinik hastalara göre daha yüksek oranda gözlendi $(p<0.05)$.

Sonuç: Çalışmamızda ileri yaș, hipertansiyon, diabetes mellitus, dispne, lenfopeni bulguları ile nötrofil, CRP, LDH, troponin I ve AST değerlerindeki yükselmenin ağır klinik tablo ile ilişkili olduğu gösterilmiştir. Bu bulguların, COVID-19 hastalarında klinik sınıflar arasındaki farkların anlaşılmasında yardımcı olabileceği düşünülmektedir.

Anahtar Kelimeler: SARS-CoV-2; COVID-19; CRP; Bilgisayarlı tomografi

Geliș Tarihi/Received: 18/02/2021 - Kabul Ediliș Tarihi/Accepted: 28/05/2021

${ }^{\bullet}$ Telif Hakkı 2021 Flora. Makale metnine www.floradergisi.org web adresinden ulașılabilir 


\title{
ABSTRACT \\ Clinical Classification of SARS-CoV-2 Positive Patients; Evaluation of Laboratory and Radiological Findings
}

\author{
Șinasi KARVAR', Harun GÜLBUDAK', Yusuf GÖRGÜLÜ', Seda TEZCAN ÜLGER', Gülden ERSÖZ2, \\ Mukadder ÇALIKOG̃LU ${ }^{3}$, Mehmet Burak Yavuz ÇiMEN ${ }^{4}$, Yüksel BALCI $^{5}$, Asena Ayça ÖZDEMiR 6 , \\ Gamze YAPICl', Nuran DELIALIOG̃LU', Gönül ASLAN'
}

\footnotetext{
${ }^{1}$ Department of Medical Microbiology, Mersin University Faculty of Medicine, Mersin, Turkey

${ }^{2}$ Department of Infectious Diseases and Clinical Microbiology, Mersin University Faculty of Medicine, Mersin, Turkey

${ }^{3}$ Department of Chest Diseases, Mersin University Faculty of Medicine, Mersin, Turkey

${ }^{4}$ Department of Medical Biochemistry, Mersin University Faculty of Medicine, Mersin, Turkey

${ }^{5}$ Department of Radiology, Mersin University Faculty of Medicine, Mersin, Turkey

${ }^{6}$ Department of Medicine Education, Mersin University Faculty of Medicine, Mersin, Turkey
}

\begin{abstract}
Introduction: The sudden emergence and rapid spread of the Coronavirus disease 2019 (COVID-19) pandemic caused by SARS-CoV-2 has dangered global health. For this reason, there has been an urgent need to develop strategies to control the spread of the virus. In this study, we aimed to evaluate the clinical, laboratory and chest computed tomography (CT) findings of COVID-19 cases with positive results of SARS-CoV-2 reverse transcription quantitative polymerase chain reaction (RT-qPCR).
\end{abstract}

Materials and Methods: A total of 278 patients aged 18 years and over who had positive SARS-CoV-2 RT-qPCR results and had access to laboratory and chest CT examinations between 15 April 2020 and 31 August 2020 were included in the study. Clinical classification of patients was performed as asymptomatic, mild and severe. Demographic information, laboratory tests and chest CT results of the patients were created with the data obtained from the hospital system and the relevant branch physicians. The data were analyzed statistically.

Results: In the study, 150 (54\%) of the patients were males and 128 (46\%) were females. Forty-two (15\%) of these patients were classified as asymptomatic, 200 (72\%) as mild and 36 (13\%) as severe cases. Mean age of the patients was found to be $45.5 \pm 17.5$ years and 72 (25.9\%) patients were found to have at least one comorbidity. Findings consistent with COVID-19 pneumonia were observed in the chest CT examinations of $42.4 \%$ (118/278) of the patients. The rate of findings in chest CT of severe patients (91.7\%) was found higher than mild (38.5\%) and asymptomatic cases (19\%) $(p<0.05)$. When we examined the laboratory findings; $59.4 \%$ of the patients had elevated CRP, 42.1\% lymphopenia, $41.1 \%$ elevated $L D H, 40.6 \%$ elevated creatinine, 36\% elevated AST, $20.1 \%$ leukopenia, 8\% elevated ALT, 7.2\% elevated leukocyte, 5.4\% elevated troponin I and 3.3\% elevated CK-MB were detected. In severe patients, lymphopenia (83.3\%), neutrophil elevation (41.7\%), CRP elevation (97.2\%), LDH elevation (91.3\%), troponin I elevation (21.4\%) and AST elevation (63.9\%) findings were observed at a higher rate than asymptomatic and mild cases $(p<0.05)$.

Conclusion: In our study, it was shown that the findings of high age, hypertension, diabetes mellitus, dyspnea, lymphopenia and the increase in neutrophil, $C R P, L D H$, troponin I and AST values were associated with severe clinical presentation. These findings are thought to be helpful in understanding the differences between clinical classes in COVID-19 patients.

Key Words: SARS-CoV-2; COVID-19; CRP; Computed tomography

\section{GíRiș}

Koronavirüsler zarflı, pozitif polariteli, segmentsiz RNA virüslerinden olușan genis bir ailedir ${ }^{[1]}$. Koronavirüsler memelilerde ve kușlarda gastrointestinal sistem ve solunum yolu infeksiyonlarına neden olur ${ }^{[1]}$. Farklı türlerde dolașan koronavirüslerin genomlarında biriken mutasyonlar, infeksiyonun türler arası yayilmasinda rol oynamaktadır ${ }^{[2]}$.

Son 20 yilda siddetli akut solunum yolu sendromu koronavirüsü (SARS-CoV; 2002) ve Orta doğu solunum yolu sendromu koronavi- rüsü (MERS-CoV; 2012) salgınından sonra 3. kez zoonotik bir koronavirüs türü, salgına neden olmuștur. Siddetli akut solunum yolu sendromu koronavirüsü 2 (SARS-CoV-2) olarak adlandır1lan bu virüs, Cin'den bütün dünyaya yayllarak pandemiye yol açmıștır ${ }^{[3]}$. SARS-CoV-2'nin neden olduğu hastalık "koronavirüs infeksiyon hastalı̆̆ı (COVID-19)" olarak adlandırılmıștır. COVID-19 laboratuvar tanisinda kullanılan standart yöntem gerçek zamanlı ters transkripsiyonlu polimeraz zincir reaksiyonu (RT-qPCR)'dur. Test negatifliğinin COVID-19 infeksiyonunu dıșlamayacağı gibi viral 
RNA pozitifliğinin de aktif ve infeksiyöz virüs varlığına kanıt olmadığı dikkate alınmalıdır [2].

SARS-CoV-2, insanlarda asemptomatik tablodan, hafif üst solunum yolu infeksiyonu, solunum yetmezliği veya ölümle sonuçlanabilen ağır viral pnömonilere kadar çeșitli klinik sonuçlara neden olabilmektedir ${ }^{[3,4]}$. Bazı hastalarda prognoz hizla kötüleșerek solunum yetmezliği ve akut solunum sıkıntısı sendromu (ARDS) gelișmektedir ${ }^{[5]}$. Özellikle ileri yaș grubu hastalarda dispne belirtisi olmadan hipoksemi ve solunum yetmezliği (Sessiz hipoksemi) gelișmektedir[6]. COVID-19'a bağlı mortalite ve morbiditenin azaltılması için hastalığın hafif klinikten, ağır kliniğe ilerlemesinin erken tespiti önemlidir ${ }^{[7]}$. Bu amaçla hastaların yaș, cinsiyet ve komorbidite durumları da göz önünde bulundurularak ceșitli laboratuvar parametreleri ve toraks bilgisayarlı tomografi (BT) verileri kullanılmaktadir ${ }^{[5]}$.

Bu calıșmada Mersin Úniversitesi Tıp Fakültesi Hastanesi Tibbi Mikrobiyoloji Laboratuvarında SARS-CoV-2 RT-qPCR sonucu pozitif olan asemptomatik, hafif klinik ve ağır klinik olarak s1nıflandırılmıs olguların klinik, laboratuvar ve toraks BT bulgularının değerlendirilmesi amaçlanmıștır.

\section{MATERYAL ve METOD}

Bu çalıșma, T.C. Sağlık Bakanlığı Sağlık Hizmetleri Genel Müdürlüğui Bilimsel Calıșma Platformu'ndan izin alınarak (Tarih: 15.06.2020 ve Karar No: Aslan-2020-06-15T21_47_33) ve Mersin Üniversitesi Klinik Araștırmalar Etik Kurulu onayı ile gerçeklestirildi (Tarih: 30.09.2020 ve Karar No: 2020/665).

Calıșmaya, 15 Nisan - 31 Ağustos 2020 tarihleri arasında Mersin Üniversitesi Hastanesinde SARS-CoV-2 RT-qPCR testi pozitif olan, laboratuvar ve toraks BT tetkiklerine ulașlan, 18 yaș ve üstü toplam 278 hasta dahil edildi. Calıșmada COVID-19 laboratuvar tanısı, viral nükleik asit tampon (vNAT) solüsyonu içine alınan nazofarengeal sürüntï örneklerinden Bio-speedy SARSCoV-2 RT-qPCR detection kitleri (Bioeksen, İstanbul, Türkiye) kullanılarak RT-qPCR Rotor-Gene Q 5plex (Qiagen, Almanya) cihazında yapıldı. Hastaların demografik bilgileri, laboratuvar tetkikleri ve toraks BT sonucları hastane sistemi ve ilgili branș hekimlerinden alınan verilerle olușturuldu.
Hastalar asemptomatik, hafif klinik ve ağır klinik olarak sınıflandırıldı. Hastaneye bașvuru sirasında klinik bulgusu olmayan hastalar "asemptomatik" olarak değerlendirildi. Ates, kas/eklem ağrıları, öksürük ve boğaz ağrısı gibi bulguları olup, solunum sayısı <30/dakika olan, oda havasinda oksijen satürasyonu $\left(\mathrm{SpO}_{2}\right)>\% 90$ üzerinde olan hastalar "haif klinik", klinik bulgulara eșlik eden takipnesi (P30/dakika) veya oda havasında $\mathrm{SpO}_{2}$ düzeyi $<\% 90$ altında olan, bir ya da daha fazla organ disfonksiyonu gelișen ve yoğun bakım ihtiyacı olan tüm hastalar "ağır klinik" olarak değerlendirildi ${ }^{[8]}$

Hastalarin COVID-19 süphesiyle hastaneye bașvurusundan sonraki 24 saat içerisinde alınan ilk kanından çalıșlan lökosit, nötrofil, lenfosit, C-reaktif protein (CRP), kreatinin, aspartat aminotransferaz (AST), alanin aminotransferaz (ALT), troponin I, kreatin kinaz-MB (CK-MB) ve laktat dehidrogenaz (LDH) değerleri, klinik sınıflara göre analiz edildi. Laboratuvar parametreleri referans

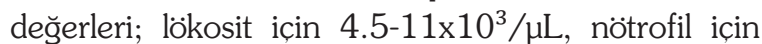
1.5-6.7 $\times 10^{3} / \mu \mathrm{L}$, lenfosit için $1.5-4 \times 10^{3} / \mu \mathrm{L}$, CRP için $<5 \mathrm{mg} / \mathrm{L}$, kreatinin için 05-0.9 mg/dL, AST için $<32 \mathrm{U} / \mathrm{L}$, ALT için $<55 \mathrm{U} / \mathrm{L}$, troponin I için <0.02 ng/mL, CK-MB için 0.6-6.3 ng/mL, LDH için 135-214 U/L olarak alındı.

Toraks BT'de pnömoni veya alveolar hasar bulgusu olan; buzlu cam görünümü, konsolidasyon alanları, kaldırım tașı görünümü veya interlobüler septal kalınlașma varlığı COVID-19 ile uyumlu bulgular olarak değerlendirildi.

\section{İstatiksel Analiz}

Sürekli değișkenlerin normallik kontrolü Shapiro Wilk testi ile yapıldı. Normal dağılıma uygunluk gösterenler için gruplar arası ortalama karșılaștırmasında Tek Yönlü Varyans Analizi, post hoc testlerden ise Tukey kullanıldı. Normal dağılıma uygunluk göstermeyenler için medyan karșlaștırmasında Kruskall Wallis testi kullanıldı. Kategorik verilerin analizinde ise Ki-Kare testi uyguland. Verilerin analizi SPSS 21 programında yapıldı. İstatistik anlamllık seviyesi 0.05 olarak alındı.

\section{BULGULAR}

Hastanemizde, 15 Nisan-31 Ağustos 2020 tarihleri arasında 13.747 hastanın 16.994 nazofarengeal sürüntü örneği SARS-CoV-2 RT-qPCR 
yöntemiyle calıșılmıș ve 1.930 (\%14) hasta pozitif bulunmustur. PCR testi pozitif, 18 yas ve üzerinde olan, laboratuvar verileri ve toraks BT tetkiklerine ulașılan, 150 (\%54)'si erkek 128 (\%46)'i kadın toplam 278 hasta calıșmaya dahil edilmiștir. Bu hastaların 42 (\%15)'si asemptomatik, 200 (\%72)'ü hafif ve 36 (\%13)'sı ağır klinik olarak sınıflandırılmıstır. Calıșmadaki hastaların 114 (\%41)'ü poliklinik, 139 (\%50)'u yataklı servis ve 25 (\%9)'i yoğun bakım ünitesinde takip edilen hastalardan olușmaktadir.

Hastaların yaș ortalaması $45.5 \pm 17.5$ (18-92) yıl olarak tespit edilmiștir. Ağır klinik hastaların yas ortalaması $60.2 \pm 15.1$ (22-89), hafif 44.0 \pm 17.2 (18-92) ve asemptomatik $40.1 \pm 14.6$ (19-80) hastalardan yüksek gözlenmiștir $(p<0.05)$. Calıșmadaki 278 hastanın 72 (\%25.9)'sinde en az bir komorbidite olduğu tespit edilmiștir ve ağır klinik hastalarda (\%61.5) hafif (\%22.5) ve asemptomatik hastalara (\%11.9) göre daha yuiksek gözlenmiștir $(p<0.05)$. Ağır klinik hastalarda hipertansiyon ve diabetes mellitus görülme sıklıkları hafif ve asemptomatik hastalara göre daha yüksek bulunmustur $(p<0.05)$. Kronik böbrek yetmezliği olan 3 hastanın hepsi ağır klinik sınıfta yer almaktadır. Klinik sinıflara göre yas, cinsiyet dağılımı ve komorbid hastalık oranları Tablo 1'de verilmiștir.
Hastaneye basvuru sirasinda hastalarda en s1k saptanan semptomlar; öksürük (\%44.1), ates (\%39.4), dispne (\%26.3), boğaz ağrısı (\%25.5), halsizlik (\%25), anosmi (\%8.9), bas ağrısı (\%8.5), diyare (\%7.6) ve miyalji (\%4.7) olarak gözlenmiștir. Dispne sıklığı ağır klinik hastalarda (\%61.1), hafif kliniğe (\%20) göre daha yüksek bulunmuștur ( $<<$ 0.001). Boğaz ağrısı sıklığı ise hafif klinik hastalarda (\%28), ağır kliniğe (\%8.3) göre daha yüksek bulunmuștur ( $p=0.036)$. Diğer semptomlar açısından hasta grupları arasında istatiksel olarak anlamlı fark bulunmamıștır ( $p>0.05$ ) (Tablo 2).

Hastaneye bașvuru sırasında hastaların 141 (\%50.7)'i COVID-19 pozitif olduğu bilinen bir hasta ile temas öyküsü belirtmiștir. Ağır klinik hastalarda temas öyküsü $(\% 25, n=9 / 36)$, hafif $(\% 52, n=104 / 200)$ ve asemptomatik hastalara (\%66.7, n= 28/42) göre daha düșuik tespit edilmiștir $(p<0.05)$. Hastaneye yatıșı olan hastaların medyan yatıs süresi 5 [4-7] gün olarak bulunmuștur. Ağır klinik hastaların medyan yatıș süresi 13 [5-17.75] gün ile hafif klinik hastalardan 5 [4-7] yüksek bulunmuștur $(p<0.05)$. Ağır klinik sınıfta 10 (\%21) hasta eksitus olmuștur.

Hastaların \%42.4 (118/278)'ünün toraks BT'sinde COVID-19 pnömonisi ile uyumlu en az bir bulgu gözlenmiștir. Ağır klinik hastaların toraks BT'sinde bulgu görülme oranı (\%91.7; n=

Tablo 1. Hastaların klinik sınıflara göre yaş, cinsiyet dağılımı ve komorbid hastalıkları

\begin{tabular}{|c|c|c|c|c|c|}
\hline & $\begin{array}{c}\text { Asemptomatik } \\
(n=42) \\
\text { Sayı (\%) }\end{array}$ & $\begin{array}{l}\text { Hafif klinik } \\
(n=200) \\
\text { Sayı }(\%)\end{array}$ & $\begin{array}{l}\text { Ağır klinik } \\
(n=36) \\
\text { Sayı (\%) }\end{array}$ & $\begin{array}{l}\text { Toplam } \\
(\mathrm{n}=278) \\
\text { Sayı (\%) }\end{array}$ & \\
\hline $\begin{array}{l}\text { Yaş (yıl) } \\
\text { Ort } \pm \text { SS } \\
\text { Min-max }\end{array}$ & $\begin{array}{l}40.1 \pm 14.6 \\
\quad(19-80)\end{array}$ & $\begin{array}{l}44.0 \pm 17.2 \\
(18-92)\end{array}$ & $\begin{array}{l}60.2 \pm 15.1^{*} \\
\quad(22-89)\end{array}$ & $\begin{array}{l}45.5 \pm 17.5 \\
\quad(18-92)\end{array}$ & $<0.001 \dagger$ \\
\hline $\begin{array}{l}\text { Cinsiyet } \\
\text { Erkek } \\
\text { Kadın }\end{array}$ & $\begin{array}{l}25(59.5) \\
17(40.5)\end{array}$ & $\begin{array}{c}98(49) \\
102(51)\end{array}$ & $\begin{array}{l}13(36.1) \\
23(63.9)\end{array}$ & $\begin{array}{l}150(54) \\
128(46)\end{array}$ & $0.265 y ́$ \\
\hline $\begin{array}{l}\text { Komorbiditeler } \\
\text { Hipertansiyon } \\
\text { Diabetes mellitus } \\
\text { Kardiyovasküler hastalık } \\
\text { Kronik akciğer hastalığı } \\
\text { Malignite } \\
\text { Hipotiroidi } \\
\text { Kronik böbrek yetmezliği }\end{array}$ & $\begin{array}{c}5(11.9) \\
2(4.8) \\
2(4.8) \\
1(2.4) \\
0 \\
0 \\
2(4.8) \\
0\end{array}$ & $\begin{array}{c}45(22.5) \\
19(9.5) \\
15(7.5) \\
12(6) \\
12(6) \\
5(2.5) \\
1(0.5) \\
0\end{array}$ & $\begin{array}{c}22(61.5)^{\star} \\
8(22.2)^{\star} \\
8(22.2)^{\star} \\
4(11.1) \\
5(13.9)^{\star *} \\
2(5.6) \\
1(2.8) \\
3(8.3) \emptyset\end{array}$ & $\begin{array}{l}72(25.9) \\
29(10.4) \\
25(9) \\
17(6.1) \\
17(6.1) \\
7(2.5) \\
4(1.4) \\
3(1.1)\end{array}$ & $\begin{array}{l}<0.001 y ́ \\
0.030 y ́ \\
0.010 y ́ \\
0.274 y ́ \\
0.038 y ́ \\
0.295 y ́ \\
0.083 y ́ \\
<0.001 y ́\end{array}$ \\
\hline \multicolumn{6}{|c|}{$\begin{array}{l}\text { †: Tek Yönlü Varyans Analizi, ý: Ki-Kare test } \\
\text { *: Asemptomatik ve hafif klinikten yüksek olanı ifade eder }(p<0.05) \text {. } \\
\text { **: Asemptomatikten yüksek olanı ifade eder }(p<0.05) \text {, ๆ: hafif klinikten yüksek olanı ifade eder }(p<0.05) \text {. }\end{array}$} \\
\hline
\end{tabular}


Tablo 2. Hastaların hastaneye başvuru sırasındaki semptomları

\begin{tabular}{lcccc} 
& $\begin{array}{c}\text { Hafif klinik } \\
(\mathbf{n}=\mathbf{2 0 0})\end{array}$ & $\begin{array}{c}\text { Ağır klinik } \\
(\mathbf{n}=\mathbf{3 6})\end{array}$ & $\begin{array}{c}\text { Toplam } \\
(\mathbf{n}=\mathbf{2 3 6})\end{array}$ & $\mathbf{p}$ \\
\hline Sayı (\%) & Sayı (\%) & Sayı (\%) & 0.610 \\
Semptomlar & & & $104(44.1)$ & 0.973 \\
Öksürük & $88(44)$ & $16(44.4)$ & $93(39.4)$ & $<0.001$ \\
Ateş & $80(40)$ & $13(36.1)$ & $62(26.3)$ & 0.036 \\
Dispne & $40(20)$ & $22(61.1)^{*}$ & $59(25.5)$ & 0.377 \\
Boğaz ağrısı & $56(28)^{*}$ & $3(8.3)$ & $59(25)$ & 0.066 \\
Halsizlik & $53(26.5)$ & $6(16.7)$ & $21(8.9)$ & 0.730 \\
Anosmi & $21(10.5)$ & 0 & $18(7.6)$ & 0.178 \\
Baş ağrısı & $20(10)$ & 0 & $11(4.7)$ & \\
Diare & $16(8)$ & $2(5.6)$ & & \\
Miyalji & $11(5.5)$ & 0 & & \\
\hline p: Ki-Kare test & & & &
\end{tabular}

33/36), hafif $(\% 38.5 ; n=77 / 200)$ ve asemptomatik hastalara $(\% 19 ; n=8 / 42)$ göre yüksek bulunmuștur $(p<0.05)$.

Hastaların laboratuvar parametreleri incelendiğinde ağır klinik hastalarda nötrofil, CRP, kreatinin, AST, troponin I ve LDH medyan değerleri hafif ve asemptomatik hastalara göre yüksek, lenfosit medyan değeri ise düsüuk bulunmuștur $(p<0.05)$. Hafif klinik hastalarda lökosit, CRP ve AST medyan değerleri asemptomatik hastalara göre yüksek bulunmuștur $(\mathrm{p}<0.05)$. Hastaların laboratuvar değerleri Tablo 3'te verilmiștir. Referans değerlere göre incelendiğinde calıșmamızdaki hastaların \%59.4'ünde CRP yüksekliği, $\% 7.2$ 'sinde lökosit yüksekliği, \%20.1'inde lökopeni, \%42.1'inde lenfopeni, \%13.3'ünde nötro- fil yüksekliği, \%5.4'ünde troponin I yüksekliği, \%3.3'ünde CK-MB yüksekliği \%40.6'sında kreatinin yüksekliği, \%36'sınde AST yüksekliği, \%8'inde ALT yüksekliği, \%41.1'inde LDH yüksekliği tespit edilmiștir. Ağır klinik hastalarda lenfopeni (\%83.3), nötrofil yüksekliği (\%41.7), CRP yüksekliği (\%97.2), LDH yüksekliği (\%91.3), troponin I yüksekliği (\%21.4) ve AST yüksekliği (\%63.9) bulguları hafif ve asemptomatik hastalara göre daha yüksek oranda gözlenmiștir $(p<0.05)$. Hafif klinik hastalarda lenfopeni (\%42), CRP yüksekliği (\%59), AST yüksekliği (\%36), lökopeni (\%24.5) bulguları asemptomatik hastalara göre daha yüksek oranda bulunmuștur $(p<0.05)$. Calıșmamızda 12 hastada troponin I yüksekliği gözlenmiștir. Bu hastaların 6'sı ağır, 6'sı hafif klinik grupta sınıflandırılmıș

Tablo 3. Hastaların bazı laboratuvar parametreleri

\begin{tabular}{lccccc} 
& $\begin{array}{c}\text { Asemptomatik } \\
(\mathbf{n}=\mathbf{4 2})\end{array}$ & $\begin{array}{c}\text { Hafif klinik } \\
(\mathbf{n}=\mathbf{2 0 0})\end{array}$ & $\begin{array}{c}\text { Ağır klinik } \\
(\mathbf{n}=\mathbf{3 6})\end{array}$ & $\begin{array}{c}\text { Toplam } \\
(\mathbf{n}=\mathbf{2 7 8})\end{array}$ & $\mathbf{p}$ \\
\hline Laboratuvar & Medyan $(\mathrm{Q} 1-\mathrm{Q} 3)$ & Medyan $(\mathrm{Q} 1-\mathrm{Q} 3)$ & Medyan $(\mathrm{Q} 1-\mathrm{Q} 3)$ & Medyan $(\mathrm{Q} 1-\mathrm{Q} 3)$ & \\
Lökosit $\left(\times 10^{3} / \mu \mathrm{L}\right)$ & $7.65(5.8-9)$ & $5.63(4.5-7.2)^{* *}$ & $6.78(5.2-8.5)$ & $5.95(4.7-7.8)$ & $<0.001$ \\
Nötrofil $\left(\times 10^{3} / \mu \mathrm{L}\right)$ & $4.34(2.9-5.2)$ & $3.39(2.4-4.5)$ & $6.21(3.7-8.3)^{*}$ & $3.55(2.5-5.1)$ & $<0.001$ \\
Lenfosit $\left(\times 10^{3} / \mu \mathrm{L}\right)$ & $2.38(1.7-2.9)$ & $1.64(1.2-2.1)$ & $0.97(0.8-1.3)^{*}$ & $1.64(1.1-2.2)$ & $<0.001$ \\
CRP $(\mathrm{mg} / \mathrm{lt})$ & $2.20(0.9-7.5)$ & $7.60(2.4-17.3)^{* *}$ & $87.44(47.1-156.6)^{*}$ & $8.11(2.2-26.9)$ & $<0.001$ \\
Kreatinin $(\mathrm{mg} / \mathrm{dL})$ & $0.81(0.6-0.9)$ & $0.81(0.6-1)$ & $0.97(0.7-1.1)^{*}$ & $0.83(0.6-1.0)$ & 0.009 \\
AST $(\mathrm{U} / \mathrm{L})$ & $22.5(18-26.5)$ & $27(21-35)^{* *}$ & $38.5(25.25-59)^{*}$ & $26(21-35)$ & $<0.001$ \\
ALT $(\mathrm{U} / \mathrm{L})$ & $20(13-30)$ & $24(16-34)$ & $27(16.2-43.2)$ & $23(15-34)$ & 0.148 \\
Troponin I $(\mathrm{ng} / \mathrm{mL})$ & $0.002(0.002-0.004)$ & $0.003(0.002-0.005)$ & $0.008(0.005-0.02)^{*}$ & $0.003(0.002-0.006)$ & $<0.001$ \\
CK-MB $(\mathrm{ng} / \mathrm{mL})$ & $1.2(0.9-2)$ & $1.1(0.7-1.8)$ & $1.1(0.5-2.3)$ & $1.1(0.7-1.9)$ & 0.386 \\
LDH $(\mathrm{U} / \mathrm{L})$ & $188(160-242)$ & $201(172-233)$ & $291(227-404)^{*}$ & $206(173.5-248)$ & $<0.001$ \\
\hline
\end{tabular}

p: Kruskal-Wallis test, CRP: C-reaktif protein, ALT: Alanin aminotransferaz, AST: Aspartat aminotransferaz, CK-MB: Kreatinin kinaz-miyokard izoenzimi, LDH: Laktat dehidrogenaz.

${ }^{\star}$ Asemptomatik ve hafif klinikten farklı olanı ifade eder $(p<0.05)$.

${ }^{\star *}$ Asemptomatikten farklı olanı ifade eder $(p<0.05)$. 
Tablo 4. Hastaların bazı laboratuvar bulguları

\begin{tabular}{|c|c|c|c|c|c|}
\hline & $\begin{array}{l}\text { Asemptomatik } \\
\quad(n=42)\end{array}$ & $\begin{array}{l}\text { Hafif klinik } \\
(n=200)\end{array}$ & $\begin{array}{l}\text { Ağır klinik } \\
(\mathrm{n}=36)\end{array}$ & $\begin{array}{l}\text { Toplam } \\
(n=278)\end{array}$ & $\mathbf{p}$ \\
\hline & Sayı (\%) & Sayı (\%) & Sayı (\%) & Sayı (\%) & \\
\hline \multicolumn{6}{|l|}{ Laboratuvar } \\
\hline Lökosit yüksekliği & $5(11.9)$ & $9(4.5)$ & $6(16.7) \rrbracket$ & $20(7.2)$ & $<0.001$ \\
\hline Lökopeni & $1(2.4)$ & $49(24.5)^{\star *}$ & $6(16.7)^{\star *}$ & $56(20.1)$ & $<0.001$ \\
\hline Nötrofil yüksekliği & $5(11.9)$ & $17(8.5)^{\star \star *}$ & $15(41.7)^{*}$ & $37(13.3)$ & $<0.001$ \\
\hline Lenfopeni & $3(7.1)$ & $84(42)^{\star *}$ & $30(83.3)^{*}$ & $117(42.1)$ & $<0.001$ \\
\hline CRP yüksekliği & $12(28.6)$ & $118(59)^{* *}$ & $35(97.2)^{*}$ & $165(59.4)$ & $<0.001$ \\
\hline Kreatinin yüksekliği & $14(33.3)$ & $78(39)$ & $21(58.3)$ & $113(40.6)$ & 0.091 \\
\hline AST yüksekliği & $5(11.9)$ & $71(36)^{\star * *}$ & $23(63.9)^{*}$ & $99(36)$ & $<0.001$ \\
\hline ALT yüksekliği & $2(4.8)$ & $17(8.6)$ & $3(8.3)$ & $22(8)$ & 0.701 \\
\hline Troponin I yüksekliği & $0(0)$ & $6(3.8)$ & $6(21.4)^{*}$ & $12(5.4)$ & $<0.001$ \\
\hline CK-MB yüksekliği & $1(2.8)$ & $4(2.6)$ & $2(8.3)$ & $7(3.3)$ & 0.059 \\
\hline LDH yüksekliği & $13(37.1)$ & $47(33.8)$ & $21(91.3)^{*}$ & $81(41.1)$ & $<0.001$ \\
\hline
\end{tabular}

Cp: Ki-Kare test, CRP: C-reaktif protein, ALT: Alanin aminotransferaz, AST: Aspartat aminotransferaz, CK-MB: Kreatinin kinaz-miyokard izoenzimi, LDH: Laktat dehidrogenaz.

*Asemptomatik ve hafif klinikten yüksek olanı ifade eder $(p<0.05)$.

${ }^{* *}$ Asemptomatikten yüksek olanı ifade eder $(p<0.05)$, $\rrbracket$ : Hafif klinikten yüksek olanı ifade eder $(p<0.05)$.

ve 4 'ü eksitus olmuștur. Hastaların laboratuvar bulguları Tablo 4'te verilmiștir.

\section{TARTIȘMA}

COVID-19 salgını, insan sağlığını ve hayatını tehdit eden yeni ortaya clkan bir durumdur. Aralik 2019'da Çin'de ortaya çkan ve bütün dünyaya yayılan koronavirüs pandemisi 2021 Şubat ayı itibarıla dünya genelinde 100 milyon, ülkemizde ise 2.5 milyonun üzerinde doğrulanmıs vaka sayısına ulașmıștır ve bu sayı hızla artmaya devam etmektedir ${ }^{[9,10]}$. Hastalığın klinik, laboratuvar ve radyolojik özellikleriyle ilgili faktörler, prognozu göstermede önemlidir ${ }^{[1]}$. Bu calıșmada SARSCoV-2 RT-qPCR testi pozitif olan olgular klinik olarak sınıflandirılarak laboratuvar parametreleri ve toraks BT bulguları değerlendirilmiștir. Calıșmada değerlendirdiğimiz 278 hastanın \%15.2'si asemptomatik, \%71.9'u hafif ve \%12.9'u ağır klinik olarak sınıflandırılmıstır. Mortalite oranı ise \%3.5 olarak tespit edilmiștir. Çin'de 72.314 doğrulanmıș vakanın incelendiği geniș ölçekli bir çalıșmada hastaların \%81'i hafif, \%14'ü ağır, \%5'i ise kritik hasta olarak sınıflandırılmıș ve mortalite oranı \%2.3 olarak bildirilmiștir ${ }^{[11]}$.

SARS-CoV-2 RT-qPCR testi pozitif olgularda ileri yas, erkek cinsiyet ve komorbidite varlığının ağır hastalık riskini arttırdığı bildirilmiștir ${ }^{[11-13]}$. Bizim çalıșmamızda hastaların \%54'ü erkek, \%46'sı kadın olup; hastaların yaș ortalaması $45.5 \pm$
17.5 yıl olarak tespit edilmiștir. Ağır klinik hastaların yas ortalaması $(60.2 \pm 15.0)$, hafif $(44.0 \pm$ 17.2) ve asemptomatik $(40.1 \pm 14.6)$ hastalardan daha yüksek gözlenmiștir $(p<0.05)$. Klinik sınıflar arasında cinsiyet dağılımı açısından istatistiksel bir fark saptanmamıștır. Calıșmamızdaki hastaların 72 (\%25.9)'sinde en az bir komorbid hastalık olduğu tespit edilmiștir ve ağır klinik hastalarda komorbidite sıklığının (\%61.5), hafif (\%22.5) ve asemptomatik hastalardan (\%11.9) daha yüksek olduğu gözlenmiștir $(p<0.05)$.

COVID-19 hastalarında en sık bildirilen komorbiditeler hipertansiyon, diabetes mellitus, kardiyovasküler hastalıklar ve kronik akciğer hastalıklarıdır $^{[12,14]}$. COVID-19 hastalarındaki komorbidite oranlarını inceleyen bir meta-analiz calıșmasında; hipertansiyon \%21.1, diabetes mellitus \%9.7, kardiyovasküler hastalık \%8.4 ve kronik akciğer hastalığı \%1.3 oranında bildirilmiștir ${ }^{[14]}$. Bașka bir meta-analiz calıșmasında ise komorbidite oranlar1; hipertansiyon \%18.6, kardiyovasküler hastalık \%14.4, diabetes mellitus \%11.9, kronik karaciğer hastalığı \%3, maligniteler $\% 2.5$ ve KOAH \%1.8 olarak bildirilmiștir ${ }^{[12]}$. Calıșmamızda komorbidite sıklıkları benzer sekilde hipertansiyon (\%10.4), diabetes mellitus (\%9), kardiyovasküler hastalık (\%6.1), kronik akciğer hastalığı (\%6.1) olarak gözlenmiștir. Ağır klinik hastalarda hipertansiyon (\%22.2) ve diabetes mellitus (\%22.2) görülme 
sıklığı hafif ve asemptomatik hastalara göre daha yuiksek bulunmuștur ( $p<0.05)$. COVID-19 hastalarında ağır hastalık riskinin; hipertansiyonu olanlarda 2.3 kat, diabetes mellitusu olanlarda 2 kat arttığı gösterilmiștir ${ }^{[14]}$. Kronik böbrek yetmezliği olan 3 hastanın tamamı ağır klinik grupta sınıflanmıștır. Kronik böbrek yetmezliği ve COVID-19 ilișkisinin değerlendirildiği bir calıșmada, kronik böbrek yetmezliği olan hastalarda COVID-19'un ağır seyretme riskinin 3 kat arttı̆̆ı gösterilmiștir $^{[15]}$

Calıșmaya dahil edilen hastaların 141 (\%50.7)'inde hastaneye bașvuru anında bilinen bir temas öyküsü bulunmaktadır. Ağır klinik hastalarda temas öyküsü (\%25), hafif (\%52) ve asemptomatik hastalardan (\%66.7) daha düșük tespit edilmiștir $(\mathrm{p}<0.05)$. Bu durum ileri yas ve hipertansiyon, diabetes mellitus, kardiyovasküler hastalık, kronik akciğer hastalığı gibi komorbiditeleri olan risk grubundaki kișilerde COVID-19 tanısında temas öyküsü öneminin düșük olduğuna ișaret etmektedir.

COVID-19 infeksiyonunda en sik görülen semptomlar; ateș, öksürük, halsizlik ve dispne olarak bildirilmiștir ${ }^{[12,14]}$. Bir meta-analiz çalıșmasında en yaygın görülen klinik semptomların ates (\%91.3), öksürük (\%67.7), yorgunluk (\%51.0) ve dispne (\%30.4) olduğu gösterilmiștir[14]. Ülkemizde yapılan bir çalısmada, COVID-19 hastalarında en sık öksürük (\%93), ates (\%42), dispne (\%22), halsizlik (\%8) ve boğaz ağrısı (\%7) semptomları bildirilmiștir ${ }^{[13]}$. Calıșmamızdaki hastalarda kaydedilen semptomlar ise sırasılla; öksürük (\%44.1), ates (\%39.4), dispne (\%26.3), boğaz ağrısı (\%25.5), halsizlik (\%25), anosmi (\%8.9), baș ağrısı (\%8.5), diyare (\%7.6), miyalji (\%4.7) seklinde gözlenmiștir.

COVID-19 infeksiyonunda hematolojik, biyokimyasal ve koagülasyon testlerinde patolojik değișiklikler görülebilmektedir ${ }^{[16]}$. Yapılan meta-analiz çalıșmaları; lökosit, CRP, AST, LDH ve CK değerlerinin artması ile lökopeni, lenfopeni ve trombositopeni bulgularının ağır klinik ile ilișkili olduğunu göstermiștir ${ }^{[8,17]}$. Calıșmamızdaki hastaların \%59.4'ünde CRP yüksekliği, \%7.2'sinde lökosit yüksekliği, \%20.1'inde lökopeni, \%42.1'inde lenfopeni, \%13.3'ünde nötrofil yüksekliği, \%5.4'ünde troponin I yüksekliği, \%3.3'ünde $\mathrm{CK}-\mathrm{MB}$ yüksekliği \%40.6'sında kreatinin yüksekliŏi, \%36'sında AST yüksekliği, \%8'inde ALT yüksekliği, \%41.1'inde LDH yüksekliği tespit edilmiștir. Ağır klinik hastalarda lenfopeni (\%83.3), nötrofil yüksekliği (\%41.7), CRP yüksekliği (\%97.2), LDH yüksekliği (\%91.3), troponin yüksekliği (\%21.4) ve AST yüksekliği (\%63.9) bulguları hafif ve asemptomatik hastalara göre daha yüksek oranda gözlenmiștir $(p<0.05)$. Hafif klinik hastalarda lenfopeni (\%42), CRP yüksekliği (\%59), AST yüksekliği (\%36), lökopeni (\%24.5) bulguları asemptomatik hastalara göre daha yüksek oranda bulunmuștur ( $p<$ 0.05). COVID-19 hastalarında troponin I yüksekliği yaygın olarak gözlenmese de ağır vakalarda görülme sıklı̆̆ı hafif vakalara kıyasla önemli ölçüde yüksektir ${ }^{[18]}$. Calıșmamızda 12 hastada troponin I yüksekliği gözlenmiștir. Bu hastaların 6's1 ağır, 6'sı hafif klinik grupta sınıflandırılmıștır ve 4'ü eksitus olmuștur.

COVID-19'da en yaygin görülen toraks BT bulguları sırasıyla; buzlu cam görünümü, septal kalınlașma ve konsolidasyon alanlarıdır ${ }^{[17,19]}$. Toraks BT bulgularının incelendiği bir meta-analiz çalıșmasında COVID-19 hastalarında herhangi bir toraks BT bulgusu görülme oranı \%89 (\%50-100) olarak tespit edilmiștir [17]. Cin'de ve İtalya'da yapılan iki farklı calıșmada pnömonili hastalarda toraks BT duyarlılığı \%97 olarak raporlanmıștir $^{[19,20]}$. Diamond Princess adl yolcu gemisinden 104 vakanın değerlendirildiği bir calıșmada, semptomatik hastaların \%79'unda ve asemptomatik hastaların \%54'ünde en az bir toraks BT bulgusu tespit edilmiștir ${ }^{[21]}$. Bir meta-analiz çalısmasına göre COVID-19 hastalarında seçili hasta gruplarının incelendiği taraflı calıșmalarda ortalama toraks BT duyarlılığı \%94 iken tüm hasta gruplarını kapsayan tarafsız calıșmalarda bu oran \%75 olarak tespit edilmiștir ${ }^{[22]}$. Bizim calıșmamızdaki hastaların 118 (\%42.4)'inde en az bir toraks BT bulgusu tespit edilmiștir. Hasta sınıflarına göre incelendiğinde ağır klinik sınıftaki hastalarda \%91.7, hafif klinik hastalarda \%38.5 ve asemptomatik hastalarda ise sadece \%19 oranında toraks BT bulgusu gözlenmiștir. Özellikle asemptomatik ve hafif klinik hastalarda akciğer tutulumunun daha az gözlenmesi radyolojik bulguların da az olacağı anlamına gelmektedir. Calıșma sonucumuz, toraks BT bulgularının hastaların klinik durumuna göre değiștiğini ve toraks BT bulgu oranlarının ağır hastalardan olușan çalıșma popuilasyonlarında daha yüksekken; hafif klinik ve asemptomatik 
hasta popülasyonlarında daha düșük olduğu sonucunu desteklemektedir. Amerikan Radyoloji Derneği, anormal toraks BT bulgularının COVID-19'a spesifik olmayacağı gibi, normal toraks BT'nin de COVID-19 tanısını dıșlamayacağını bildirmiștir [23].

Sonuc olarak çalıșmamızda asemptomatik, hafif ve ağır klinik hasta grupları değerlendirilmiștir. Elde ettiğimiz sonuçlara göre; ileri yas, hipertansiyon, diabetes mellitus, dispne, lenfopeni, nötrofil yüksekliği, CRP yüksekliği, LDH yüksekliği, troponin I yüksekliği ve AST yüksekliği ağır klinik ile ilișkili bulunmuștur. Ayrıca ağır klinik hastalarda daha yüksek oranda toraks BT bulgusu gözlenmiștir. Bu bulguların, COVID-19 hastalarında klinik sınıflar arasındaki farkların anlașılmasında yardımcı olabileceği düșünülmüștür. Ancak özellikle ileri yas ve komorbiditenin eșlik ettiği olgularda laboratuvar ve radyolojik bulguların normal olmasına rağmen kliniğin ağır seyredebileceği unutulmamalıdır.

\section{ETIK KURUL ONAYI}

Çalıșma için, Mersin Üniversitesi Klinik Araștırmalar Etik Kurulu'ndan onay alındı (Tarih: 30.09.2020, Karar No: 665).

\section{ÇIKAR ÇATIŞMASI}

Yazarlar tarafından herhangi bir çıkar çatıșmaS1 bildirilmemiștir.

\section{YAZAR KATKISI}

Anafikir/Planlama: GA, STÜ, SKK

Analiz/Yorum: SK, GA, YG,ND

Veri Sağlama: GE, MÇ, BC,, YB, GY

Yazım: SK, HG

Gözden Geçirme ve Düzeltme: GA, ST, GE Onaylama: GA

\section{KAYNAKLAR}

1. Fehr AR, Perlman S. Coronaviruses: an overview of their replication and pathogenesis. Methods Mol Biol 2015;1282:123.

2. Erensoy S. COVID-19 Pandemisinde SARS-CoV-2 ve Mikrobiyolojik Tanı Dinamikler [SARS-CoV-2 and Microbiological Diagnostic Dynamics in COVID-19 Pandemic]. Mikrobiyol Bul 2020;54(3):497-509.

3. Epidemiology Working Group for NCIP Epidemic Response, Chinese Center for Disease Control and Prevention. [The epidemiological characteristics of an outbreak of 2019 novel coronavirus diseases (COVID-19) in China]. Zhonghua Liu Xing Bing Xue Za Zhi 2020;41(2):145-51.
4. Bulut C, Kato Y. Epidemiology of COVID-19. Turk J Med Sci 2020;50(SI-1):563-70.

5. Xie Y, Wang Z, Liao H, Marley G, Wu D, Tang W. Epidemiologic, clinical, and laboratory findings of the COVID-19 in the current pandemic: systematic review and meta-analysis. BMC Infect Dis 2020;20(1):640.

6. Xie J, Tong Z, Guan X, Du B, Qiu H, Slutsky AS. Critical care crisis and some recommendations during the COVID-19 epidemic in China. Intensive Care Med 2020;46(5):837-40.

7. Wu X, Liu L, Jiao J, Yang L, Zhu B, Li X. Characterisation of clinical, laboratory and imaging factors related to mild vs. severe covid-19 infection: a systematic review and meta-analysis. Ann Med 2020;52(7):334-44.

8. T.C. Sağlık Bakanlı̆̆ COVID-19 Erişkin Hasta Tedavisi Rehberi. Erişim tarihi: 12 şubat 2021. Available from: https:// covid19.saglik.gov.tr/Eklenti/39061/0/covid-19rehberieriskinhastatedavisipdf.pdf

9. World Health Organization (WHO). Erişim tarihi: 12 şubat 2021. Available from: https://www.who.int/emergencies/ diseases/novel-coronavirus-2019

10. T.C. Sağlık Bakanlığı COVID-19 Bilgilendirme Sayfası. Erişim tarihi: 12 Şubat 2021. Available from: https://covid19. saglik.gov.tr/TR-66935/genel-koronavirus-tablosu.html (Erişim tarihi: 12 şubat 2021)

11. Wu Z, McGoogan JM. Characteristics of and Important Lessons From the Coronavirus Disease 2019 (COVID-19) Outbreak in China: Summary of a Report of 72314 Cases From the Chinese Center for Disease Control and Prevention. JAMA 2020;323(13):1239-42.

12. Rodriguez-Morales AJ, Cardona-Ospina JA, Gutiérrez-Ocampo E, Villamizar-Peña R, Holguin-Rivera Y, Escalera-Antezana JP, et al. Clinical, laboratory and imaging features of COVID-19: A systematic review and meta-analysis. Travel Med Infect Dis 2020;34:101623.

13. Günal Ö, Türe E, Bayburtlu M, Arslan U, Demirağ MD, Taşkın MH, et al. COVID-19 Tanılı Hastaların Risk Faktörleri Açısından Değerlendirilmesi [Evaluation of Patients Diagnosed with COVID-19 in Terms of Risk Factors]. Mikrobiyol Bul 2020;54(4):575-82.

14. Yang J, Zheng Y, Gou X, Pu K, Chen Z, Guo Q, et al. Prevalence of comorbidities and its effects in patients infected with SARS-COV-2: a systematic review and meta-analysis. Int J Infect Dis 2020;94:91-95.

15. Henry BM, Lippi G. Chronic kidney disease is associated with severe coronavirus disease 2019 (COVID-19) infection. Int Urol Nephrol 2020;52(6):1193-94.

16. Pourbagheri-Sigaroodi A, Bashash D, Fateh F, Abolghasemi $H$. Laboratory findings in COVID-19 diagnosis and prognosis. Clin Chim Acta 2020;510:475-82.

17. Borges do Nascimento IJ, von Groote TC, O'Mathúna DP, Abdulazeem HM, Henderson C, Jayarajah $U$, et al. International Task Force Network of Coronavirus Disease 2019 (InterNetCOVID-19). Clinical, laboratory and radiological characteristics and outcomes of novel coronavirus (SARSCoV-2) infection in humans: A systematic review and series of meta-analyses. PLoS One 2020;15(9):e0239235. 
18. Lippi G, Lavie Cl, Sanchis-Gomar F. Cardiac troponin I in patients with coronavirus disease 2019 (COVID-19): Evidence from a meta-analysis. Prog Cardiovasc Dis 2020;63(3):390-91.

19. Ai T, Yang Z, Hou H, Zhan C, Chen C, Lv W, et al. Correlation of Chest CT and RT-PCR Testing for Coronavirus Disease 2019 (COVID-19) in China: A Report of 1014 Cases. Radiology 2020;296(2):E32-E40.

20. Caruso $D$, Zerunian $M$, Polici $M$, Pucciarelli F, Polidori $T$, Rucci C, et al. Chest CT Features of COVID-19 in Rome, Italy. Radiology 2020;296(2):E79-E85.

21. Inui S, Fujikawa A, Jitsu $M$, Kunishima $N$, Watanabe $S$, Suzuki $Y$, et al. Chest CT Findings in Cases from the Cruise Ship "Diamond Princess" with Coronavirus Disease 2019 (COVID-19). Radiol Cardiothorac Imaging 2020;2(2):e200110.

22. Waller IV, Allen IE, Lin KK, Diaz MJ, Henry TS, Hope MD. The Limited Sensitivity of Chest Computed Tomography Relative to Reverse Transcription Polymerase Chain Reaction for Severe Acute Respiratory Syndrome Coronavirus-2 Infection: A Systematic Review on COVID-19 Diagnostics. Invest Radiol 2020;55(12):754-61.
23. American College of Radiology(ACR). Erişim tarihi: 12 Şubat 2021. Available from: https://www.acr.org/Advocacy-and-Economics/ACR-Position-Statements/Recommendations-for-Chest-Radiography-and-CT-for-Suspected-COVID19-Infection

\section{Yazıșma Adresi/Address for Correspondence}

Dr. Gönül ASLAN

Mersin Üniversitesi Tip Fakültesi,

Tıbbi Mikrobiyoloji Anabilim Dalı,

Mersin-Türkiye

E-posta: drgaslan@gmail.com 